\title{
THE ELEGIAC ASS: THE CONCEPT OF SERVITIVM AMORIS IN APULEIUS' METAMORPHOSES
}

\author{
Judith Hindermann
}

Seruitium amoris, the notion of love as slavery, is a frequent theme in Roman elegy.' It inverts Roman reality in representing a free Roman citizen dominated by a woman, evidently from a lower social class. The elegiac amator ('lover') elevates his beloved puella ('girl') and treats her as a slave would treat his mistress (domina), obeying her orders and yielding to her wishes and moods. Although it has been widely observed that Lucius, the protagonist of Apuleius' Metamorphoses, acts like a slave towards his beloved, the slave girl Fotis, the idea of elegiac seruitium amoris has not been analysed systematically as an explanation of this strange relationship, and affinities between the Metamorphoses and Roman elegy have even been denied altogether. ${ }^{2}$ To date, most investigations have focused not on the mode but on the consequences of Lucius' servile behaviour, culminating in his transformation into an ass and a series of painful adventures brought to an end by the intervention of the goddess Isis.

My discussion will argue that in presenting Lucius and Fotis as an elegiac couple, Apuleius adds yet another form of love to the broad spectrum of relationships between the sexes that he presents in the Metamorphoses. It will also contend that by introducing the theme of seruitium amoris, he helps his audience interpret the complex and richly described relationship between protagonist and slave, a key theme throughout the work.

The fact that Lucius' relationship to the other main female character in the novel, the goddess Isis with whom Fotis shares many features, shows also typically elegiac elements makes it possible to reopen the old discussion concerning the relationship of the first ten books to the eleventh, to reinterpret Lucius' 'conversion' and through it the meaning of the whole novel.

\section{Lucius and Fotis: amator and puella}

The actual status of Lucius as free citizen and of Fotis as slave is stressed in a lengthy scene at Met.1.22-24 before it is reversed into an elegiac seruitium amoris. Lucius arrives as an uninvited guest to the home of the avaricious Milo, whose only attendant Fotis is told to chase away beggars and petitioners. She will not admit the stranger, and treats him in a rather unfriendly fashion. Finally, Milo invites Lucius to his house and commands the ancillula ('little maid', Met. 1.23) Fotis to unpack the guest's luggage and bring oil and towels for the bath. In addition, Lucius asks Fotis to buy feed for his horse.

The relationship between Lucius and Fotis also appears to be entirely professional during their second meeting that evening (Met. 1.26). Fotis, who is again 


\section{JUDITH HINDERMANN}

described by the term ancilla ('maid'), merely performs her duties by calling the guest (hospes) Lucius for dinner with her master Milo. There is no hint of a future liaison.

Whereas Fotis is characterised explicitly as a slave by being referred to twice as ancilla, and by being described as performing servile duties such as watching the door and running errands, Lucius' noble rank is emphasised from the start of the novel. The very first piece of information with which the reader is provided after the prologue is a reference to the narrator's illustrious pedigree. ${ }^{3}$ In addition, we are told in the second book, immediately before his affair with Fotis commences, that Lucius' noble birth is also recognisable in his appearance. Two independent sources, Lucius' host Milo and his acquaintance Byrrhena, praise his distinguished features. ${ }^{4}$

During their love affair, however, the relationship between Lucius and Fotis is perverted into its opposite, in accordance with the rules of the elegiac world. The slave Fotis becomes a mistress, and the free citizen Lucius changes into a slave of love. The reversal of their social roles is perceptible in their changed behaviour. It is no longer Lucius who gives orders to Fotis; instead, he submits to her imperious moods. While they flirt in the kitchen Fotis gives Lucius an order to go away, but also tells him to beware of her, and prepare for their sexual encounter. ${ }^{5}$ In the nocturnal love scene that follows, Fotis remains dominant by telling Lucius explicitly what she wants him to do. ${ }^{6}$

The protagonist of the Metamorphoses displays submissive behaviour towards Fotis not only in the privacy of night, but also in the bright light of day. He does not accept an invitation from Byrrhena, his mother's close friend and important member of Hypata's elite social world, until his domina Fotis gives him permission to do so:

ergo igitur Fotis erat adeunda deque nutu eius consilium uelut auspicium petendum. quae quamquam inuita, quod a se ungue latius digrederer, tamen comiter amatoriae militiae breuem commeatum indulsit.

(Met.2.18)

Therefore I had to ask Fotis for permission and to interpret her nod as a piece of advice or an omen. Even though she didn't like me to go away from her further than the width of a nail, she generously allowed a short break from my military service of love.

Like a slave, Lucius has no right to go where he wants to. He is tied to the house and has to ask his mistress for permission to leave. The impression of Lucius' complete dependence on his beloved is strengthened by the detail that he waits for her nod, nutus. This word is often used in the Metamorphoses in connection with the power of goddesses: Fortune (Met. 4.12; 7.20; 10.24), Juno (Met. 6.4; 10.31), Venus (Met. 6.16) and Isis (Met. 11.1; 11.5; 11.21; 11.25) all express their will wordlessly in this way. ${ }^{7}$ By associating Fotis with this ges- 
ture, Lucius classes her with the goddesses who appear in his novel, thus elevating her above the human sphere, as he does elsewhere in the work by comparing her with Venus, goddess of love. ${ }^{8}$

In addition to the motifs of seruitium amoris and the deification of the beloved, Apuleius introduces another elegiac theme. Lucius not only begs his beloved Fotis humbly for permission to go to a dinner party without her, but also entreats her for a short break from his military service of love. Whereas in the epitome of the Greek Metamorphoses the love affair between the protagonist and his beloved is described in wrestling-metaphors (Onos 8-10), Apuleius changes Lucius into a soldier of love whose only duty and mode of earning honour is to serve his lover. Therefore we have in a short scene a combination of three typical elegiac motifs: militia amoris, seruitium amoris and the notion of the beloved as a goddess.

Although Lucius acts like a slave, he does not have to experience the typical worries and pains of an elegiac lover. His mistress Fotis is not, moreover, a dura puella ('harsh girl'). She is not cruel, but kind and generous; the relationship between the lovers appears to be relaxed and full of mutual affection. As a survey of the different forms assumed by seruitium amoris in Roman elegy indicates, this specific, more endurable, variety of the motif prominently surfaces in Ovid's Ars Amatoria.

Holzberg ${ }^{9}$ asserts that the theme of seruitium amoris is found most frequently in the elegies of Propertius. While Propertius tries to impart a deeper ethical sense to love's slavery, at the same time he attempts to free himself from servile submission. By way of contrast, Tibullus does not question his own, unsuccessful enslavement. In Ovid's Amores, the theme of seruitium amoris plays a very minor role. In the Ars Amatoria, moreover, it reverses into its own opposite. There, in his adopted role of a praeceptor amoris, Ovid wants his students to be successful in their endeavours. He consequently changes the meaning of seruitium amoris: no longer is it an end in itself, but merely a means to the end of securing the affections and favours of a woman.

As Wildberger ${ }^{10}$ has documented, Ovid wants to save his students from the terrible sorrows and pains that the elegiac lover has to endure. Thus he teaches a 'light' version of seruitium amoris as part of his love-lore. Instead of the traditional, pathological slavery of love, Ovid develops the conception of a voluntary obsequium amoris ('compliance in love'), which does not create emotional dependency and prevents masochistic excesses. To achieve this goal, the student of love - unlike the elegiac amator - has to remain emotionally independent, and to avoid love that is too passionate or too submissive.

Ovid advises that the student of love should seek to dominate and structure the relationship according to his wishes. Such an arrangement does not prevent him from being indulgent to his female beloved, or even from letting her have her way at times. Occasionally, the student of love even has to perform slavish tasks for her. But he never truly obeys his beloved, and simply lets her play the role of the more powerful partner. In this way, the student of love may use 


\section{JUDITH HINDERMANN}

seruitium amoris as a pose, for having a relationship that suits him. Ovid thus upgrades the role of the slave of love by teaching that it has to be assumed, for the sake of deceiving the female lover.

We now turn to how the protagonist of Apuleius' Metamorphoses follows this elegiac advice. Lucius not only behaves towards Fotis as if he were a slave, but also twice describes himself as one. The first time he does so is in the third book of the Metamorphoses, after Fotis has explained to him the reasons for his humiliating trial in front of the citizens of Hypata. Lucius wants Fotis to show him her mistress Pamphile in the act of performing magic. To grant this wish, Lucius uses two strategies. On the one hand, he appeals to Fotis' guilty conscience. Owing to her, he maintains, he became a laughing stock in Hypata during the Risus-trial. On the other hand, he flatters her by confessing his servile submission:

scio istud et plane sentio...tuis istis micantibus oculis et rubentibus bucculis et renidentibus crinibus et hiantibus osculis et fraglantibus papillis in seruilem modum addictum atque mancipatum teneas uolentem. iam denique nec larem requiro nec domuitionem paro et nocte ista nihil antepono.

(Met. 3.19)

I know this and I feel it for sure...I'm addicted to your beaming eyes and your red cheeks and your shining hair and opened lips and fragrant breasts like a slave and you hold me as a voluntary servant. I don't miss my home and I'm not preparing to leave and I don't appreciate anything more than that night with you.

The protagonist explains his state of mind, which alienates him from his social position and duties - symbolised by larem ('home-god') and domuitionem ('journey home') - with his dedication to Fotis' beauty. The description of Fotis' external appearance makes clear what the reasons for Lucius' slavery are. In choosing certain parts of the body to highlight, and certain adjectives to describe them, Lucius observes that it is not magic but Fotis' sexual power that enthralls him. Lucius praises her fragrant breasts, her opened lips, her beaming eyes, her red cheeks and her shining hair. At the same time, Lucius underlines his free will by using first person singular forms of the verb three times (nec requiro...nec paro...nihil antepono, 'I don't miss...I'm not preparing...I appreciate nothing') and the present participle of uelle, 'to be willing' (uolentem). The protagonist does not express himself as if he were a desperate victim, but an utterly free man, who enslaves himself voluntarily. To ensure Fotis of his fidelity, he enumerates in a tricolonic phrase (nec...nec...et nihil) all of the things that night of love (nocte ista) have now rendered unimportant to him.

Further evidence of Lucius' servile submission appears in the description of how his relationship with Fotis ends. While Fotis generously enables Lucius to 


\section{THE ELEGIAC ASS}

watch her mistress performing magical rites, she does not like him to practice magic by himself. In spite of his oaths, she does not want him to change into a bird and fly away. For she doubts whether he will return to her, and suspects that he might use his new aviation skills to meet other sexual partners in the way that her mistress Pamphile does. In order to have his wish granted, Lucius flatters Fotis abundantly, and adds a promise to be her slave until the end of time:

adrepta manu Fotidis et admota meis luminibus: 'patere, oro te', inquam, 'dum dictat occasio, magno et singulari me adfectionis tuae fructu perfrui et impertire nobis unctulum indidem per istas tuas papillas, mea mellitula, tuumque mancipium inremunerabili beneficio sic tibi perpetuo pignera.'

I took Fotis' hand, moved it towards my eyes and said, 'Permit me, I beg you, as the opportunity urges, to enjoy this great and unique benefit of your love and give me a bit of the ointment from that jar-by those breasts of yours I beg you, my sweetie - and bind me to you for ever as your slave by this unrepayable favour.

With his choice of words Lucius points out that he sees himself as a voluntary and temporarily limited slave of love. He can offer his beloved the prospect of staying with her forever if she is willing to help him realise his greatest wish. He does not have to stay with her, but can choose whether he wants to be a slave or not, since he is not bound by Amor or magical spells. As an independent salesman he bargains with Fotis according to the principle of do ut des which is linked to all the commercial language he employs (fructu, inremunerabili, pignera).

It is striking that Luçius depicts himself as a slave of love only when he wants Fotis to fulfil his desire for magic. By demonstrating his emotional and physical dependence he wants to allay her fears and promises that he will stay with her even after an encounter with the world of magic. This promise, in fact, does not turn out to be true. It is also worth noticing that Lucius expects a gift in return for his submissive behaviour. As the praeceptor amoris Ovid recommends in his Ars Amatoria, Lucius never loses control of his feelings. His submission towards Fotis is not an end in itself, but a means to get in touch with magic.

\section{Lucius and Isis: seruus and domina}

There are many parallels between the novel's two main female characters Fotis and Isis who dominate the story in the beginning and in the end. Both 


\section{JUDITH HINDERMANN}

figures have a name ending in -is, wear the same hairstyle, are in a close relation to the goddess Venus, order Lucius to keep silence about their secret lore and cause his metamorphosis. In addition, Apuleius strengthens the connection between the two figures by using identical phrases and formulations to describe them. Whereas the existence of an intended relation between Fotis and Isis isn't contested in the research on Apuleius' Metamorphoses, the reason for the striking similarities between the two female figures remains controversial. Until recently a typological approach which interprets Fotis as Isis' negative anti- and prototype has been the favourite explanation." In order to reach the saviour goddess the protagonist has to overcome Fotis who is incorporated in the true goddess Isis and thereby deprived of her negative forces. The adherents of this theory claim a serious reading of the eleventh book as authentic witness of a religious experience. Thus the ending of Apuleius' Metamorphoses is taken as a reliable source for the cult of Isis in the second century $\mathrm{CE}^{12}$ and Lucius' experiences with Isis as representing those of a real devotee of the goddess. This approach seems problematic to me since the fact that Apuleius has written the end of a novel and not a scientific paper about the cult of Isis is ignored, yet often no other evidence for certain customs between believer and goddess is adduced besides the Metamorphoses. ${ }^{13}$ I would like to show in what follows that there are many conspicuous elements in the relation between Lucius and Isis, which can be explained more suitably with an intra- and intertextual approach.

First of all, there is the fact that Lucius isn't released at the end of the novel but remains a slave. Whereas the protagonist in the epitome of the Greek Onos finds his way back to his former life by shedding his asinine appearance, Lucius remains under outside control for the rest of the novel. Though he recovers his human shape, his retransformation does not turn him back into the man he was before his adventures. Thus his metamorphosis is only an external one and he is kept in his status of servitude. He not only shaves his head like a slave, ${ }^{14}$ but he is also summoned by Isis' priest to spend his life in the service of the goddess: nam cum coeperis deae seruire, tunc magis senties fructum tuae libertatis ('If you start serving the goddess, you will enjoy the fruit of your freedom more', Met. 11.15). While Lucius decides voluntarily to act towards Fotis as a slave and a soldier of love for strategic reasons, Isis' priest demands this behaviour from him. He also denounces Lucius' relation to Fotis as seruiles uoluptates ('slavish pleasures') and recommends him a new, more powerful mistress: sibi uitas <in> seruitium deae nostrae maiestas uindicauit ('The majesty of our goddess has claimed their lives for her service', Met. 11.15).

Closely related to the idea of slavery is the idea of a military duty for the goddess. Lucius not only like a slave asks Fotis for permission to leave the house, but wants a short break in his amatoriae militiae (Met. 2.18). We can find the same connection between the metaphors of slavery and military service in the priest's requesting Lucius to become a soldier and slave of Isis: 
da nomen sanctae huic militiae, cuius non olim sacramento etiam rogabaris, teque iam nunc obsequio religionis nostrae dedica et ministerii iugum subi uoluntarium.

(Met.11.15)

Sign yourself up for this holy military service, to whose oath you have been recently summoned, and dedicate yourself to the rites of our religion and voluntarily take on the yoke of this service.

The notion of freedom through servile subjection is contrary to traditional Greco-Roman values ${ }^{15}$ and not testified for the cult of Isis outside Apuleius' Metamorphoses. The notion of military service, while there is some evidence for it in the Isis cult, ${ }^{16}$ is clearly introduced here because of its associations with elegy and the 'campaigns' of the elegiac lover. ${ }^{17}$ The priest's instructions here have gone largely unremarked, possibly because the idea of slavery and military service for a god is well known from Christian sources, especially from Paul's epistles. ${ }^{18}$ The eroticism in the relationship between Lucius and Isis is coming under increasing scholarly scrutiny, but this is mostly confined to the way Lucius describes his relationship with this new mistress; ${ }^{19}$ it does not extend to a reconsideration of the contents of the priest's speech.

Part of Lucius' duty for his goddesses is his constant presence. He lives in the same house as both Fotis and Isis, which is conspicuous in the latter case, as pilgrims normally resided outside the proper cult area. According to EgelhaafGaiser ${ }^{20}$ Lucius' constant staying in the temple area is not part of the preparation for the initiation, but is grounded in his wish to be as close as possible to Isis. In order to be constantly with Fotis, whose presence Lucius values above everything else, the protagonist renounces contact with his peers by refusing Byrrhena's invitations and her offers to introduce him to the elite citizens of Hypata.

As reward for Lucius' persistent veneration both Isis and Fotis provide him uoluptas ('pleasure'). After finally having accepted Byrrhena's invitation to a dinner party, Lucius promises Fotis to return home early because he prefers the uoluptas ${ }^{21}$ with her, a slave girl, to an evening with Hypata's high-society: nam praeter quod epulis alienis uoluptates meas anteferrem ("for besides the fact that I like my pleasures more than dinner with other people..., Met. 2.18). The same addiction is evident in Lucius' relation to Isis. He enjoys her sight so much he can't break free from the uoluptas he experiences in front of her statue: paucis dehinc ibidem commoratus diebus inexplicabili uoluptate simulacri diuini perfruebar ('thereafter I spent some days there and enjoyed the inexpressible pleasure which emanated from the goddess's statue', Met. 11.24). Spending time with Isis seems to be more important for Lucius than the reunion with his friends and relatives whom he hasn't seen for at least a year. Even though he welcomes his compatriots, he soon returns back to his goddess from who he is inseparable (Met. 11.19). In his intense service Lucius forgets in both 


\section{JUDITH HINDERMANN}

cases to return home to his normal life. Earlier in the novel he tells Fotis: iam denique nec larem requiro nec domuitionem paro ('now indeed I don't miss home and I'm not preparing to return there', Met.3.19). The same happens with Isis. Eventually, the goddess herself has to tell him to leave her: sed tandem deae monitu...tardam satis domuitionem comparo, uix equidem abruptis ardentissimi desiderii retinaculis ('but finally at the goddess's urging...I made preparations for a return home, a tardy one indeed. Only narrowly could I break free from the chains of my most ardent desire', Met. 11.24). Lucius' stay in his home town is only short and not further described. Returning back in his former social environment is obviously not Lucius' goal. Consequently, he is ordered after a few days in a night-time vision to leave and to meet Isis in Rome again (Met. 11.26).

In comparison to Fotis, Isis is a much more demanding mistress. Whereas the conquest of Fotis is quite easy, Lucius has to fight hard to get access to the interior of Isis' temple, which is described with the unusual term cubiculum deae (literally 'the goddess's bedroom', Met. 11.17).$^{22}$ Like an exclusus amator ('locked-out lover') he repeatedly begs for entrance (Met. 11.21) while the priest, Isis' custos ('guardian'), defends the door. And as with the lovers in elegy (and indeed Roman comedy), he has to pay a lot of money to maintain his relationship with her $($ Met. $11.21 ; 11.22 ; 11.23 ; 11.28) .^{23}$

Another difference between Lucius' relationship with Fotis and that with Isis is the idea of an exclusive and lifelong connection, reminding one of an elegiac foedus aeternum ('everlasting bond') ${ }^{24}$ Not only does Isis' priest want Lucius to swear an oath of allegiance (Met.11.15), Isis too wants Lucius to be faithful to her his whole life: plane memineris et penita mente conditum semper tenebis mihi reliqua uitae tuae curricula adusque terminos ultimi spiritus uadata ('you must remember it well and keep it constantly buried in the depth of your mind that the remaining course of your life belongs to me till you take your last breath', Met. 11.6). Isis' statement is astonishing, as initiation in several mysteries was not unusual and Lucius himself has, as Fotis tells us, formerly been initiated into a number of cults (sacris pluribus initiatus, Met. 3.15). According to Festugière ${ }^{25}$ Isis' exclusive claim for Lucius has an 'original touch, practically unknown among the ancients, which can only be compared with religious vocation among Christians'. Lucius promises to worship Isis constantly, even when they are apart: diuinos tuos uultus numenque sanctissimum intra pectoris mei secreta conditum perpetuo custodiens imaginabor ('I will hide your divine face and your most holy divinity in the core of my heart, where I will preserve and contemplate them forever', Met. 11.25). Whereas with Fotis the protagonist remains always in full control of the situation and keeps his free will despite his gestures of subjection, he appears in his relation to Isis as dependent and servile. He can't apply strategies like the Ovidian student of love and thereby keep his emotional freedom. Isis is a true domina of the kind we encounter in Tibullus or Propertius, whom Lucius can't manipulate as he did with Fotis. It's Isis who is in control, and Lucius who obeys. 


\section{THE ELEGIAC ASS}

To sum up: In my opinion, the assumption that Book 11 is basically a religious text where mundane love has no place has led critics to overlook the erotic undertone and the striking parallels between elegiac amator and religious devotee. But Apuleius' depiction of Lucius as Isis' slave, soldier and ardent admirer should send an important signal to the reader that this is not the way to read this final book. If, as has been suggested recently by many scholars, one reads it not in contrast, but in continuation to the first ten books, and at the same time not as the serious report of a convert, but as a literary play with different texts and traditions, the parallels between an elegiac lover and this religious believer are striking. This representation of the relationship between devotee and goddess as seruus and domina raises serious questions about a onedimensional interpretation of the eleventh book. ${ }^{26}$

\section{Universität Basel}

\section{NOTES}

1. Cf. the diachronic investigations of R.O.A.M. Lyne, 'Seruitium amoris', $C Q$ n.s. 29 (1979), 117-30 and of P. Murgatroyd, 'Seruitium amoris and the Roman Elegists', Latomus 40 (1981), 589606.

2. P. James, Unity in Diversity: A Study of Apuleius' Metamorphoses with Particular Reference to the Narrator's Art of Transformation and the Metamorphosis Motif in the Tale of Cupid and Psyche (Hildesheim/Zürich/New York 1987) accords the most emphasis to the importance of elegiac seruitium amoris in Apuleius' Metamorphoses. She calls Lucius' behaviour towards Fotis an 'ardent and effusive courtship, exhibiting all the features of seruitium amoris' and Fotis 'the recipient of a number of elegiac flatteries' (52). Furthermore, she assumes that Lucius 'in his manufactured infatuation with Fotis...deliberately reversed their social roles and took the seruitium amoris pose to great lengths' (243f.). G. Sandy, 'Seruiles Voluptates in Apuleius' Metamorphoses', Phoenix 28 (1974), 234-44, also judges Roman elegy the model for Lucius' 'exaggerated profession of his love and enslavement' (238), but sees him more as a slave of magic than of sexual lust. V. Schmidt, 'Apuleius Met. 3,15f.: Die Einweihung in die falschen Mysterien', Mnem. 35 (1982), $269-82$, at 278 , rejects the possibility that the idea of seruitium amoris is present in the novel because Fotis also calls herself a slave to Lucius.

3. Thessaliam-nam et illic originis maternae nostrae fundamenta a Plutarcho illo inclito ac mox Sexto philosopho nepote eius prodita gloria $<m>$ nobis faciunt ('to Thessaly - for that's where my family's roots are, going back on my mother's side to the famous Plutarch and later his nephew the philosopher Sextus, which I'm very proud of', Met. 1.2). The Latin text is here and throughout taken from Helm's third edition (Leipzig 1931); the translations are my own.

4. etiam de ista corporis speciosa habitudine deque hac uirginali prorsus uerecundia, generosa stirpe proditum et recte conicerem ('I would have guessed - and rightly - your belonging to a good family also from your attractive personal appearance and from your maidenly shyness', Met. 1.23); en...sanctissimae Saluiae matris generosa probitas ("you show the good manners of your most venerable mother Salvia', Met. 2.2).

5. discede...quam procul a meo foculo, discede ('go away...go away as far from my little oven as you can', Met. 2.7); caue ('be cautious', Met. 2.10); bono animo esto...abi ergo ac te compara ('be confident...go away now and prepare yourself', Met. 2.10).

6. proeliare...et fortiter proeliare...derige et grassare nauiter et occide moriturus ('fight...and fight bravely...straighten up, give it all you've got and kill me as if you were about to die', Met. 2.17). 


\section{JUDITH HINDERMANN}

7. The word nutus is similarly employed for Mercury (Met. 10.30), the emperor (Met. 7.7) and Isis' priest (Met. 11.14). In Met. 2.30 and 3.12 nutibus describes the behaviour of the curious community and in Met. 10.17 Lucius' gesture as a 'trained' ass.

8. Met. $2.17 ; 3.22$.

9. N. Holzberg, 'Ovids erotische Lehrgedichte und die römische Liebeselegie', WS n.f. 15 (1981), 185-204, at 198-204.

10. J. Wildberger, Ovids Schule der 'elegischen' Liebe: Erotodidaxe und Psychagogie in der Ars Amatoria (Frankfurt a. M./Berlin/Bern 1998), 214-32.

11. E.g. A. Wlosok, 'Zur Einheit der Metamorphosen des Apuleius', Philologus 113 (1969), 6884, at 78; J.L. Penwill, 'Slavish Pleasures and Profitless Curiosity: Fall and Redemption in Apuleius' Metamorphoses', Ramus 4 (1975), 49-82, at 71; Schmidt (n.2 above); R. de Smet, 'The Erotic Adventure of Lucius and Fotis in Apuleius' Metamorphoses', Latomus 46 (1987), 613-23; $\mathrm{K}$. Alpers, 'Innere Beziehungen und Kontraste als hermeneutische Zeichen in den Metamorphosen des Apuleius von Madaura', WJA n.f. 6a (1980), 197-207, at 199-201; J.K. Krabbe, The Metamorphoses of Apuleius (New York/Bern/Frankfurt a.M./Paris 1989), 84-86; Sandy (n.2 above); E.J. Kenney, Apuleius: Cupid and Psyche (Cambridge 1990), 11; H. Münstermann, Apuleius Metamorphosen literarischer Vorlagen: Untersuchung dreier Episoden des Romans unter Berïcksichtigung der Philosophie und Theologie des Apuleius (Stuttgart/Leipzig 1995), 16-23; 44f. D. van Mal-Maeder Apuleius Madaurensis Metamorphoses, livre II: texte, introduction et commentaire (Groningen 2001), 410, argues against this sharp division between the first ten and the eleventh book and interprets the Isis-book not in opposition, but in continuation to the rest of the novel.

12. A.-J. Festugière, Personal Religion among the Greeks (Berkeley/Los Angeles 1954); U. Egelhaaf-Gaiser, Kulträume im römischen Alltag: das Isisbuch des Apuleius und der Ort von Religion im kaiserzeitlichen Rom (Stuttgart 2000); R. Merkelbach, Isis regina-Zeus Sarapis: die griechisch-ägyptische Religion nach den Quellen dargestellt (Stuttgart/Leipzig 1995).

13. Merkelbach (n.12 above), 300; R. Turcan, Les cultes orientaux dans le monde romain (Paris 1989), 112; R.E. Witt, Isis in the Graeco-Roman World (Ithaca NY 1971), 135.

14. Cf. D. van Mal-Maeder, 'Lector, intende: laetaberis: The Enigma of the Last Book of Apuleius' Metamorphoses', GCN 8 (1997), 87-118, at $100 \mathrm{f}$.

15. Cf. F. Bömer, Untersuchungen über die Religion der Sklaven in Griechenland und Rom, Erster Teil (Wiesbaden 1957), 390f.; Zweiter Teil (Wiesbaden 1960), 89f.; 128; 133-41.

16. See J. Gwyn Griffiths, Apuleius of Madauros: The Isis Book (Metamorphoses, Book X1) (Leiden 1975), 254f.

17. Cf. e.g. Ov. Am. 1.9, 2.12; Ars 2.233-36; Prop. 2.1.47, 2.7.15-18; A. Spies, Militat omnis amans: ein Beitrag zur Bildersprache der antiken Erotik (Diss. Tübingen 1930).

18. For the development of the metaphors of military service in early Christianity see A. von Harnack, Militia Christi: die christliche Religion und der Soldateneid in den ersten drei Jahrhunderten (Darmstadt 1963); A. Wlosok, 'Römischer Religions- und Gottesbegriff in heidnischer und christlicher Zeit', in E. Heck, E. Schmidt and A. Ernst (eds.), Res humanae - res diuinae. Kleine Schriften (Heidelberg 1990), 15-34, at 29f. For the Christian notion of 'slavery of God' cf. Rom. 1.1; 6.22; Gal. 5.1; Luke 1.38; Mt. 11.29 and H. Versnel, Inconsistencies in Greek and Roman Religion I. Ter Unus: Isis, Dionysos, Hermes: Three Studies in Henotheism (Leiden 1990), $90 f$.

19. E.g. J.L. Penwill, 'Ambages Reciprocae: Reviewing Apuleius' Metamorphoses', Ramus 19 (1990), 1-25, who writes that Lucius 'in a very real sense...has merely substituted one mistress for another' (12). Versnel (n.18 above) notices an 'amatory ring' (91) in Lucius' voluntary submission. See also G. Schmeling and S. Montiglio, 'Riding the Waves of Passion: An Exploration of an Image of Appetites in Apuleius' Metamorphoses', in W.H. Keulen, R.R. Nauta and S. Panayotakis (eds.), Lectiones Scrupulosae (Groningen 2006), 28-41.

20. Egelhaaf-Gaiser (n.12 above), $442 \mathrm{f}$.

21. For Lucius' uoluptas with Fotis cf. Met. 2.10;2.17.

22. Cf. Egelhaaf-Gaiser (n.12 above), 160.

23. Cf. e.g. the situation of Philolaches in Plautus' Mostellaria and the advice of the procuresses in Prop. 4.5 and Ov. Am. 1.8 .

24. Cf. Tib. 1.6.85f.; Prop. 1.12.20, 2.6.41f., 2.25.9f.; Wildberger (n.10 above), 262-64 and 32229.

25. Festugière (n.12 above), 80.

26. This article is an expanded version of a paper I gave at ICAN IV, the fourth International Conference on the Ancient Novel, Fundação Calouste Gulbenkian, Lisbon 21-26 July 2008. 